Viana Hassan,

Lebanese University, Faculty of Tourism and Hospitality, Lebanon

Lecturer at University of Malta, Malta

Miloš Zrnić,

Academy of Applied Studies Belgrade, The College of Hotel Management

DOI 10.5937/turpos0-34456

UDK 338.483.13:392.7/.8(569.3)

338.48-026.512.3

\title{
SLOW TOURISM: A NICHE MARKET TOWARDS SUSTAINABILITY OF MOONLIGHT FARM HOUSE „BAROUK AREA“
}

\section{SPORI TURIZAM: TRŽIŠNA NIŠA ODRŽIVOSTI MOONLIGHT FARM KUĆE „BAROUK AREA“}

\begin{abstract}
Abstact: Slow tourism is one of the new trending concepts that bring the concept of slowness into tourism practices in the way that tourists appreciate local food, culture, heritage, and sustainability.

Destinations adopting principles of slow tourism may reduce the financial leakage of the suppliers and generate more income and employment to the locals. Thus, the case of ,Moonlight farm and Resort at Barouk" area, is the core topic for this study to understand the relation between slow tourism, sustainable development and ecology, which has the roots in interest for locality, community, and green travel.

The main research question is „How can slow tourism be a tool of sustainable development?". In order to answer this, a mixed-method approach was conducted through the use of two questionnaires addressed to tourists visiting ,,Moonlight farm “ and residents in Barouk area. Additionally, an interview with the owner provided signifcant insight into the topic. The analysis of the results was beneficial in understanding the perceptions and motivations of tourists and helping promote slow tourism in this area.
\end{abstract}

Key words: Barouk, Moonlight, slow tourism, sustainable development, niche market
Apstrakt: Spori turizam je jedan od novih trendova koji koncept sporosti uvodi u turističke prakse na način da turisti cene lokalnu hranu, kulturu, nasleđe i održivost.

Destinacije koje usvajaju principe sporog turizma mogu smanjiti finansijsko curenje dobavljača $i$ ostvariti veći prihod $i$ zapošljavanje lokalnog stanovništva. Tako je „Moonlight Farms and Resorts in Baruk“ ključni primer koji ilustruje $i$ omogućava razumevanje veza između sporog turizma $i$ održivog razvoja.

Glavno istraživačko pitanje je: „Kako spori turizam može biti oruđe za održivi razvoj? “. Da bi se odgovorilo na ovo, pristup mešovitim metodama sproveden je korišćenjem dva upitnika namenjena turistima koji posećuju „Mеsečevu farmu“ i stanovnicima oblasti Baruka. Osim toga, intervju sa vlasnikom bi pružio značajan uvid u temu. Analiza rezultata bila je korisna u razumevanju percepcija $i$ motivacije turista koji pomažu u promociji sporog turizma $u$ ovoj oblasti.

Ključne reči: Baruk, Mesečeva farma, spori turizam, održivi razvoj, tržišna niša 


\section{Introduction}

Slow tourism is one of the new trending concepts that bring the model of slowness into tourism practices in a way that tourists appreciate the local food, culture, heritage, and sustainability. According to the world travel market, it can apply away from the conventional tourism (Guiver \& McGrath, 2017), however, slow tourism lessens the pace of activity, by trying each activity in its own right (Molz, 2009; Lumsdon and McGrath, 2011). Term "slow tourism“" is contrasted with active tourism where tourism involves multiple stops and activities. Additionally, the benefits of slow tourism are not only on the environment (Guiver \& McGrath, 2017). Moreover, destinations adopting principles of slow tourism may reduce the financial leakage of the suppliers and generate more income and employment to the locals (Mohamad, 2015).

This study attempted to understand the relation between slow tourism and sustainable development by taking into consideration the residents' perception and tourist motivation toward the slow tourism concept. Slow Tourism can be an addition to the tourism development for many Lebanese destinations. The researcher discusses the concept of slow tourism, by studying the tourists trend which focuses on the quality of the vacation, interaction with local people and appreciating the local cultures (Dickinson\&Lumsdon, 2010). Furthermore, the main objectives of this research indicate the relationship between slow tourism, movement, sustainable development and ecology, which has the roots in interest for locality, community, and green travel (Georgică et al., 2013).

\section{Literature review}

Slow travel or slow tourism is relatively new concepts in the tourism industry. It came out from a broader trend of so-called „slow-movement“, which can be specified by the philosophy of „slow food“" (Moira et al., 2017) and the general philosophy of „slow city" that is known as „citta slow". According to Schneider (2008) the slow food movement found in 1989 as a dissent against the widespread of the fast-food overrunning in Europe. Later on, in 1999 the philosophy of the slow city was born and attributed to Paolo Saturnini, the mayor of the town of Greve in Chianti, Tuscany (Presenza et al., 2015).

According to Guiver \& McGrath, 2017)., slow tourism holds different meanings. Georgica 2015) defines SLOW as S-Sustainable, L-Local, O-Organic, W-Whole. Georgica (2015) emphasizes that slow traveling lets you build a keen relationship with the destination. As Moira et al. (2017) explained the three different pillars of slow travel: the first 'doing things at the right speed,' the second 'changing the attitude towards speed, and the last one is 'seeking quality over quantity.' As indicated by Georgica (2015) slow tourism follows two main facets: taking time and attachment to a particular place. Slow travelers take time to find each destination scrupulously and to experience the local culture rather than adjusting to more and more destinations or cities with each trip. So, the slowness concept is commonly taking a look at how well utilized the time is, at the quality and a feeling of prosperity (Lumsdon \& McGrath, 2011).

\section{Slow tourism dimensions}

After discussing the defining and origin of slow tourism, it is essential to understand the dimensions of slow tourism. According to Dall'Aglio et al. (2011) slow tourism consists of six dimensions:

- Time: Taking time means a modification of the daily time relationship, precisely an alternate view of nature and living in harmony with a place, its occupants, and their way of life. Tourists 


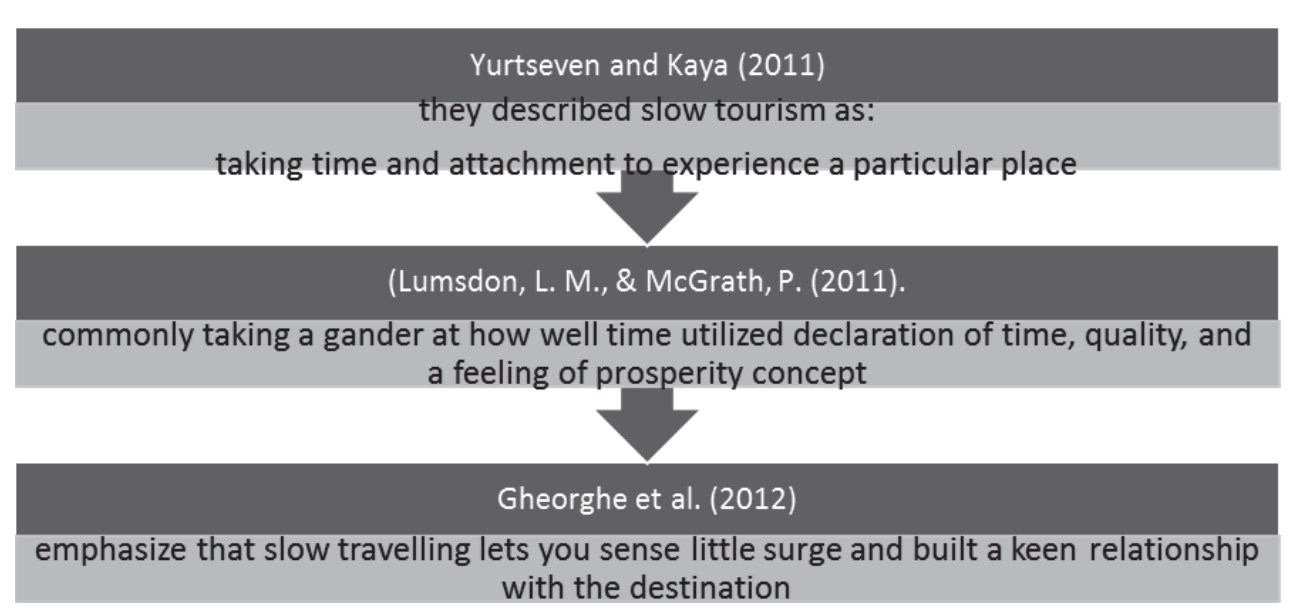

Figure 1: Definitions of slow tourism according to different authors.

Source:Kaya \& Kurt, 2011;Lumsdon, L. M., \& McGrath, P. (2011)

must have the option to change pace, to look rather than to see, to encounter the territory instead to suffer it (Mohamad Noor et al., 2015).

- Slowness: The slow tourism must satisfy two essential principles: „doing things at the right speed" (Moira et al., 2017) while attempting to change our daily propensities and ,real connection to the place."“

- Contamination: Slow tourism produces less pollution since it is more focusing on locality, the use of clean energy, reduces the carbon footprint, and ecological and ethical vision. Also, the slower experience such as activities like trekking, running, bird watching, is less aggressive for the environment, due to the less timing travel, resource reduction, and customization.

- Authenticity: There is a lot of ambiguity surrounding the term authenticity; according to Cohen (2002) authenticity is more about how you feel than something you can define. He believes that when you personally feel that something is real, and then it is real.

- Sustainability:The impact of the tour- ism activity on the local environment, broadly speaking, it claims the need for a sustainable approach that is ecologically light in the long term, economically, ethically and socially fair toward local (Mohamad Noor et al., 2015).

- Emotion: Planning and supplying the service that can empower or encourage feelings inside the arranged ad-hoc (external environment stimulus) circumstances and occasions that connects individual answers (internal) contrasting by people's understanding.

\section{Slow versus Mass tourism}

Mass tourism is a form of tourism that attracts a large number of organized tourists attending popular holiday destinations. Krippendorf in „The Holiday Makers“, refers to the mass movement of people traveling in all directions to reestablish their physical and mental well-being, without giving a meaning of the idea of ,mass tourism“ (Moira et al. 2017).

The same author additionally distinctively depicts how the voyagers, during their trip, „consume“ the climate, natural 
environment, location, culture, and individuals of the host destinations. Moreover, mass tourism rose because of the far-reaching utilization of the aircraft as a mode of transport, especially the charter flight, which made traveler transport a massive activity.

Mass transfer in a short time frame produced the requirement for massive stay and afterward for massive food and beverage services and massive tour guiding. On the other hand, Dickinson \&Lumsdon, (2010) distinguished three fundamental principles of the slow trip:

- first - get things done at the correct speed;

- second - change of one's conduct as well as speed, and
- third - identify the quest for quality over quantity.

Moira et al.(2017) contend that slow tourism refers to the slowdown of the tune of tourist travel and a redetection of our natural and psychological being. It covers different aspect as the low carbon footprint, patience, peace of mind, authenticity of the experiences, better understanding and familiarity with the culture of the host country (Moira et al., 2017).

Thus, the ,antidote“ to mass tourism is slow tourism. In this light, a feverishly organized trip ,to see as much as possible“ is replaced by a slow journey of pleasure and relaxation - the real holiday (Moira et al., 2017).

Table 1: Comparing Slow Tourism to Mass Tourism

\begin{tabular}{|l|l|}
\hline Mass Tourism & Slow Tourism \\
\hline Quick Movement & Slow Movement \\
\hline The airplane is the dominant means of transport. & $\begin{array}{l}\text { Use of alternative means of transport, mainly } \\
\text { train or bus }\end{array}$ \\
\hline $\begin{array}{l}\text { Transportation with high carbon dioxide emis- } \\
\text { sions }\end{array}$ & $\begin{array}{l}\text { Transportation with low carbon dioxide emis- } \\
\text { sions }\end{array}$ \\
\hline Speed & Slow pace \\
\hline The trip coincides with the movement & The movement is part of the journey \\
\hline Visit to numerous tourist attractions & Perceiving the local character of a place \\
\hline Quantifying the visiting areas & Qualifying the tourist experience \\
\hline Passive Tourist & Active Tourist \\
\hline Standardized experiences & Authentic experiences \\
\hline Standardized food services & Local and traditional type of diet \\
\hline $\begin{array}{l}\text { Impersonal acquaintance and low contact with } \\
\text { the place and its residents }\end{array}$ & $\begin{array}{l}\text { Substantial contact and real communication with } \\
\text { the destination and its residents }\end{array}$ \\
\hline $\begin{array}{l}\text { Accommodation in commercialized resorts or } \\
\text { hotel complexes }\end{array}$ & Accommodation in small accommodation units \\
\hline Group options, lack of flexibility & Individual options, flexibility \\
\hline $\begin{array}{l}\text { Hostage - omnipresence of the communication } \\
\text { technologies during holidays }\end{array}$ & $\begin{array}{l}\text { Getting rid of the communication technologies } \\
\text { during holidays. }\end{array}$ \\
\hline
\end{tabular}

Source: Mylonopoulos\&Kondoudaki 2017

Many authors considered sustainable development as an essential pillar of slow tourism and slow movement philosophy as an efficient destination development strategy in urban areas, when in fact all forms of tourism should move toward focusing on the three pillars of sustainability: Economic, environmental and socio-cultural (Hobson \& Essex, 2001).

Researchers have attained an assent on the advantages of slow tourism; it provides opportunities for more green form for 
destinations. Eco-friendly activities, slow types of transport and regular accommodation (vacation rentals). Thus, it goes under the concept of sustainable development in which it helps to protect the environment. However, following a trend like slow movement includes a slow development of the environment at a pace and limits that permits the residents to adjust and to adapt to the advancements (Oh et al., 2016; Sharpley, 2000; Lumsdon\& McGrath, 2011).

\section{Methodology}

In this study a mixed method approach was used, actually two main research methods: two questionnaires and an interview with the director of Moonlight Farm and Resort. The first questionnaire was addressed to tourists from different nationalities and backgrounds, distributed online via personal emails over four weeks; from August 1st till September 28th 2021, to come up with the required information. This questionnaire was designed to produce summaries about how slow tourism can be a tool of sustainability, but also to identify motivation of tourists toward slow tourism. The sample size of the respondents is 50 guests, using simple random sampling.

The second questionnaire that was addressed to 50 residents of Barouk area consisted of 10 closed-ended questions, distributed with the same period and divided in two main parts. The first part includes demographic questions and the second focuses on how residents understand and interpret the slow tourism concept.

\section{Results and analysis}

According to the paradigm of mixed-method, below are presented the results of the two questionnaires and the interview; the first was addressed to 50 residents from Barouk Region and the second questionnaire with 50 tourists of Moonlight
Farm and Resort. The age group of residents and visitors dominated by $18-28$ years' segment $(40 \%)$, the second biggest age being the $29-40(40 \%)$. The other percentage distributed among the rest age groups. When it comes to gender, it is to be noticed that there were more women $(83 \%)$ than men $(17 \%)$ responding to both surveys.

When education level examined for visitors and residents it was found that $88 \%$ of respondents had attended university. The majority of the rest had attended only high school $6 \%$ and $5 \%$ holding qualifications less than high school level.

For the employment status of the residents, 56\% unemployed, 32\% employed students, and the other percentages were distributed among employed and trainee people. Out of 20 respondents, there were 7 different nationalities. The highest rank is for Maltese tourists were $45 \%$ and Lebanese visitors $30 \%$. The analysis of the second part of the survey was about the resident's perception toward slow tourism shows: $92 \%$ of participants agreed that slow tourism is a tool of sustainable development and had a positive impact on the environment.

Practicing slow tourism varies from local food, local products, to slow activities (biking, walking, and relaxing in nature). $94 \%$ of the participants practice tasting local food, $56 \%$ practice slow activities. They were asked also about suggestions what they would recommend to improve sustainable development. Obtained answers show that the majority of the respondents with $74 \%$ have chosen all the options such as (reduce carbon footprint, respect the practices of local people, take care of heritage places, etc.).

On the other hand, it was necessary to ask residents about some practices concerning the slow tourism concept. Though, several statements used Likert scale ranging from 1 to 5: strongly agree to strongly disagree. For the first statement, it was analyzed that $38 \%$ of the respondents agree on it and $16 \%$ of them strongly agreed. 
Slow tourism is the contrast of mass tourism in which organized trips are replaced by a slow journey. At this pace, the rest of the statements include that slow tourist have fixed programs during their tours, $34 \%$ of respondents agreed, and $32 \%$ answered neutral. However, slow tourists rarely had a fixed program for their trip. Besides, $44 \%$ of the respondents pointed out that those large groups of tourists might practice slow tourism. Finally, the last two phrases state if the money spent through slow tourism stays at the local community, $32 \%$ of the residents agreed, and $30 \%$ were neutral. Concerning physically slowing down tourists, $50 \%$ of answers were neutral, 32\% agreed. The bar charts of these statement's analyses can be found in the appendix number two. Majority of the guests $75 \%$ stated that they visited Moonlight for the first time. $40 \%$ stay for a weekend, $40 \%$ up to 4 days, while $20 \%$ stayed for a week.

In our research, we wanted to find out respondents' motivation and interests in Moonlight, so the visitors were asked about the reason for choosing this guesthouse, $90 \%$ for leisure, $5 \%$ business, and $5 \%$ for relaxing.Another question was addressed to the visitors about their interest; $45 \%$ for eco-friendly and sustainable, $35 \%$ for authenticity.Moreover, the $60 \%$ of visitors pointed out that the Farm is a homely environment, $45 \%$ liked the environment and the $25 \%$ stated for staff appearance.As the participants reported, 95\% liked the gastronomy and traditional dishes served and presented by Moonlight Resort. Additionally, visitors recommended improving the guesthouse to have simpler accommodation. Number of respondents $50 \%$ mentioned the relaxation facilities while, $25 \%$ reported using less technology and fewer machines.

\section{Conclusion}

After gathering all the data from the interview and questionnaire, it is appearing that slow tourism is a new, attractive con- cept for people of different ages, where the majority holds high education degreeand know how to practice slow tourism and their activities appropriately in order to lead to sustainability. Also, slow tourism surely helped the local market and visitors to be more eco-friendly, absorbing the local culture. In addition, slow tourists had plenty of time to explore a destination and immerse themselves in the experience while protecting environmental resources.

Slow tourism is a relatively new concept and many types of research have been conducted on this subject. Moreover, the slowness concept is generally looking at the time being used, deceleration of time, quality, and a sense of well-being concept. However, it was interesting to observe that visitors' and residents had awareness and knowledge toward the slow tourism concept. However, due to the limitations of data, the results might not be sufficient, while it could be helpful to other researchers who want to discuss this concept more widely.

There is a relation between slow tourism and sustainable development, due to slow concept forms as tool for sustainability, which can provide opportunities for more green form for destinations, and leads to personal development. Additionally, slow tourism is a response to the negative aspects of mass tourism; it gives more authenticity to tourists' experience.

In addition, researchers could elaborate more on the concept of slow tourism in Lebanon, as it is a wide topic and include different sections, such as:

Future studies might work more on promoting slow tourism as many tourists do not know about this new trend.

- Additional research on the current topic is needed, as it will be helpful for reference when taking a Lebanon case.

- The destinations of slow tourism should focus on the sustainability and the quality of life of the local community. 
- There is a need for a greater focus on tourism activities from the concerned authorities such as the government and the local community in order to reach sustainable development in tourism.

- Based on questionnaires, we can conclude that the majority of respondents (94\%) practice slow movement or slow activities in their daily lives without any knowledge about slow tourism by eating local food, practice slow activities, reduce the carbon footprint, by involving local people in order to improve sustainability.

\section{References}

Cohen, E. (2002). Authenticity, equity and sustainability in tourism. Journal of sustainable tourism, 10(4), 267-276.

Dall'Aglio, S., Nazzaruolo, A., \& Zago, M. (2011). Guide lines for the development of the Slow Tourism project. Retrieved, 10 (20), 2014.

Dickinson, J., \& Lumsdon, L. (2010). Slow travel and tourism. Earthscan.

Georgic, G., Bulin, D., Dorobantu, M. R., Stefania, B., \& Nistoreanu, P. (2013). Slow movement as an extension of sustainable development for tourism resources: a Romanian approach. In Proceedings of the Conference: 20th IBIMA Conference, Special Edition, Kuala Lumpur, Malaysia (pp. 25-26).

Georgica, G. (2015). The Tourist's Perception about Slow Travel - A Romanian Perspective. Procedia Economics and Finance, 23, 1596-1601.

Guiver, J., \& McGrath, P. (2017). Slow Tourism: Exploração de discursos. Dos Algarves: A Multidisciplinary e-Journal, (27), 11-34.

Hobson, K., \& Essex, S. (2001). Sustainable tourism: A view from accommodation businesses. Service Industries Journal, 21(4), 133-146.

Kaya, H., \& Kurt, H. (2011). Contribution of concrete cultural constituents to the tourism potential of Safranbolu. Procedia-Social and Behavioral Sciences, 19, 225-230.

Lumsdon, L. M., \& McGrath, P. (2011). Developing a conceptual framework for slow travel: A grounded theory approach. Journal of Sustainable Tourism, 19 (3), 265-279.

Mohamad Noor, F. A., Nair, V., \& Mura, P. (2015). Conceptualizing a framework for slow tourism in a rural destination in Malaysia. Advanced Science Letters, 21 (5), 1185-1188.

Moira, P., Mylonopoulos, D., \& Kondoudaki, A. (2017). The application of slow movement to tourism: is slow tourism a new paradigm? Journal of Tourism and Leisure Studies, 2(2), 1-10.

Molz, J. G. (2009). Representing pace in tourism mobilities: Staycations, slow travel and the amazing race. Journal of Tourism and Cultural Change, 7(4), 270-286.

Oh, H., Assaf, A. G., \& Baloglu, S. (2016). Motivations and goals of slow tourism. Journal of Travel Research, 55(2), 205-219.

Presenza, A., Abbate, T., \& Micera, R. (2015). The Cittaslow movement: Opportunities and challenges for the governance of tourism destinations. Tourism Planning \& Development, 12(4), 479-488.

Schneider, S. (2008).Good, clean, fair: The rhetoric of the slow food movement. College English, 70(4), 384-402.

Sharpley, R. (2000). Tourism and sustainable development: Exploring the theoretical divide. Journal of Sustainable tourism, 8(1), 1-19. 